\title{
Species occurrence of the potentially toxigenic diatom genus Pseudo- nitzschia and the associated neurotoxin domoic acid in the Argentine Sea
}

\author{
Gastón O. Almandoz ${ }^{\mathrm{a}, \mathrm{b}, *}$, Elena Fabro ${ }^{\mathrm{a}, \mathrm{b}}$, Martha Ferrario ${ }^{\mathrm{a}, \mathrm{b}}$, Urban Tillmann ${ }^{\mathrm{c}}$, \\ Allan Cembella ${ }^{\mathrm{c}}$, Bernd Krock $^{\mathrm{c}}$ \\ a División Ficología, Facultad de Ciencias Naturales y Museo, Universidad Nacional de La Plata. Paseo del Bosque s/n (B1900FWA), La Plata, Argentina \\ b Consejo Nacional de Investigaciones Científicas y Técnicas (CONICET), Av. Rivadavia 1917, 1033 Buenos Aires, Argentina \\ c Alfred Wegener Institut-Helmholtz Zentrum für Polar- und Meeresforschung, Ökologishe Chemie, Am Handelshafen 12, 27570 Bremerhaven, Germany
}

\section{A R T I C L E IN F O}

\section{Article history:}

Received 28 October 2016

Received in revised form 17 January 2017

Accepted 17 January 2017

Available online $\mathrm{xxx}$

\section{Keywords:}

Amnesic shellfish poisoning

South-western Atlantic

Pseudo-nitzschia diversity

P. australis

P. brasiliana

Domoic acid

\section{A B S T R A C T}

The marine diatom genus Pseudo-nitzschia, the major known producer of the neurotoxin domoic acid (DA) responsible for the amnesic shellfish poisoning (ASP) syndrome in humans and marine mammals, is globally distributed. The genus presents high species richness in the Argentine Sea and DA has been frequently detected in the last few years in plankton and shellfish samples, but the species identity of the producers remains unclear. In the present work, the distribution and abundance of Pseudo-nitzschia species and DA were determined from samples collected on two oceanographic cruises carried out through the Argentine Sea $\left(\sim 39-47^{\circ} \mathrm{S}\right)$ during summer and spring 2013. Phytoplankton composition was analysed by light and electron microscopy while DA was determined by liquid chromatography coupled to tandem mass spectrometry (LC-MS/MS). The genus Pseudo-nitzschia was recorded in 71 and $86 \%$ of samples collected in summer and spring, respectively, whereas DA was detected in only 42 and $21 \%$ of samples, respectively. Microscopic analyses revealed at least five potentially toxic species ( $P$. australis, $P$. brasiliana, $P$. fraudulenta, $P$. pungens, $P$. turgidula), plus putatively non-toxigenic $P$. dolorosa, $P$. lineola, $P$. turgiduloides and unidentified specimens of the $P$. pseudodelicatissima complex. The species $P$. australis showed the highest correlation with DA occurrence $(r=0.55 ; p<0.05)$, suggesting its importance as a major DA producer in the Argentine Sea. In the northern area and during summer, DA was associated with the presence of $P$. brasiliana, a species recorded for the first time in the Argentine Sea. By contrast, high concentrations of $P$. fraudulenta, $P$. pungens and $P$. turgidula did not correspond with DA occurrence. This study represents the first successful attempt to link toxigenicity with Pseudo-nitzschia diversity and cell abundance in field plankton populations in the south-western Atlantic.

(C) 2017 Elsevier B.V. All rights reserved.

\section{Introduction}

The marine diatom genus Pseudo-nitzschia $\mathrm{H}$. Peragallo is distributed worldwide and often represents an important, even dominant component of phytoplankton assemblages (Lelong et al., 2012). The genus now comprises 48 recognized species (Teng et al., 2014, 2015, 2016; Percopo et al., 2016), most of them described within the last two decades. Among these species, at least 23 have been mentioned as potential producers of domoic acid (DA) (Teng

\footnotetext{
* Corresponding author at: División Ficología, Facultad de Ciencias Naturales y Museo, Universidad Nacional de La Plata, Paseo del Bosque s/n (B1900FWA), La Plata, Argentina.

E-mail address: galmandoz@fcnym.unlp.edu.ar (G.O. Almandoz).
}

et al., 2015, 2016), a secondary amine neurotoxin. This neurotoxin can be accumulated throughout the marine food web, causing amnesic shellfish poisoning (ASP), a neurological syndrome with even lethal effects on sea birds, marine mammals and humans in extreme cases (Fire and Van Dolah, 2012).

The existence of toxigenic and non-toxigenic strains of the same species has been recurrently mentioned for several Pseudonitzschia species (e.g. Rhodes et al., 1996; Villac et al., 1993; Thessen et al., 2009; Sahraoui et al., 2011). Environmental factors, such as ambient nutrient concentrations, temperature, salinity, irradiance, photoperiod and $\mathrm{pH}$, have been known to influence and under some circumstances to induce DA production in laboratory culture experiments (Lelong et al., 2012; and references therein). In addition, it has been recently observed that DA toxin content 
increased when cells of Pseudo-nitzschia species were exposed to copepod grazing (Tammilehto et al., 2015; HarĐardóttir et al., 2015). In the field, however, is difficult to provide strong evidence for the association of environmental conditions with DA production by Pseudo-nitzschia species (Marchetti et al., 2004; Schnetzer et al., 2007; Guannel et al., 2015).

Toxigenic Pseudo-nitzschia species are typically found in coastal waters, whereas open-ocean strains are usually found to be nontoxigenic or producers of only very low DA cell concentrations (Marchetti et al., 2008; Trick et al., 2010). Nevertheless, it is unclear if this tendency reflects genetic distinctiveness ("ecotypes") or is largely a function of ambient environmental influences on toxin production. From a global perspective, most toxic DA events have been associated with the occurrence of Pseudo-nitzschia australis Frenguelli, which together with $P$. multiseries (Hasle) Hasle and $P$. seriata (Cleve) Peragallo present the highest per cell DA concentrations measured in laboratory cultures (Trainer et al., 2012; and references therein). In any case, there is a great inter- and intraspecific variability in DA cell quotas measured among Pseudonitzschia strains isolated into culture from different regions of the world (Trainer et al., 2012). In addition, highly variable cell quotas are typically found among natural Pseudo-nitzschia populations (Schnetzer et al., 2007; Thessen and Stoecker, 2008), but some of this apparent variability may be attributable to DA estimates based upon total cell densities of Pseudo-nitzschia, which usually includes several co-occurring species.

Several previous studies have focused on the occurrence of Pseudo-nitzschia species in coastal and shelf waters from the Argentine Sea. These taxonomic surveys, conducted exclusively by means of light and electron microscopy analyses, have revealed a high species richness at the morphological level (Negri and Inza, 1998; Ferrario et al., 1999, 2002; Sastre et al., 2001; Almandoz et al., 2007; Sunesen et al., 2009). Similarly, DA has been frequently detected in phytoplankton samples from different zones of the Argentine Sea in the last few years (Negri et al., 2004; Sastre et al., 2007; Cadaillón, 2012; Krock et al., 2015). Indeed, Pseudo-nitzschia blooms have been suggested as potentially responsible for calf mortalities of southern right whales along the Valdés Península
(D'Agostino et al., 2015; Wilson et al., 2015). During these episodes, DA production was mainly associated with elevated cell densities of $P$. australis (Negri et al., 2004) or P. fraudulenta (Cleve) Hasle (Sastre et al., 2007), but the co-occurrence of several other Pseudonitzschia species (Cadaillón, 2012; Krock et al., 2015), makes it difficult to unequivocally identify the responsible taxa. Likewise, analyses of DA toxin production of local strains of $P$. pungens (Grunow ex Cleve) Hasle (Sar et al., 2006) and P. multiseries (Montoya et al., 2008) revealed either negative or positive results, respectively, while DA production for other species found in the Argentic Sea has not been yet evaluated. All this indicate that DA production by Pseudo-nitzschia species in Argentine waters and the south-western Atlantic remains poorly understood.

In the present work, the distribution and abundance of Pseudonitzschia species and DA was analysed from two sampling cruises carried out through the Argentine Sea $\left(\sim 39-47^{\circ} \mathrm{S}\right)$, covering coastal, shelf and shelf-break waters during summer and spring 2013. The main goal was to reveal the identity of major DA producers in the field, by associating abundance and distribution of Pseudo-nitzschia species and DA.

\section{Material and methods}

\subsection{Plankton and toxin sampling}

Water samples were collected during two oceanographic expeditions in the Argentine Sea (Fig. 1). The first expedition was conducted in late austral summer on the $R / V$ Bernardo Houssay from 11 to 22 March 2013, with 24 sampling stations located between $\approx 39$ and $43^{\circ} \mathrm{S}$. This cruise was divided into two legs $\mathrm{K} 1$ and $\mathrm{K} 2$, which comprised 8 and 16 sampling stations, respectively. The second expedition was carried out in austral spring aboard the $R / V$ Puerto Deseado from 26 October to 9 November 2013, with 43 sampling stations located between $\approx 39$ and $47^{\circ} \mathrm{S}$. At each station, temperature and salinity were measured by CTD (conductivitytemperature-depth) profiler, except from leg K2 of Expedition 2, for which only temperature data were obtained with a multiparameter probe.
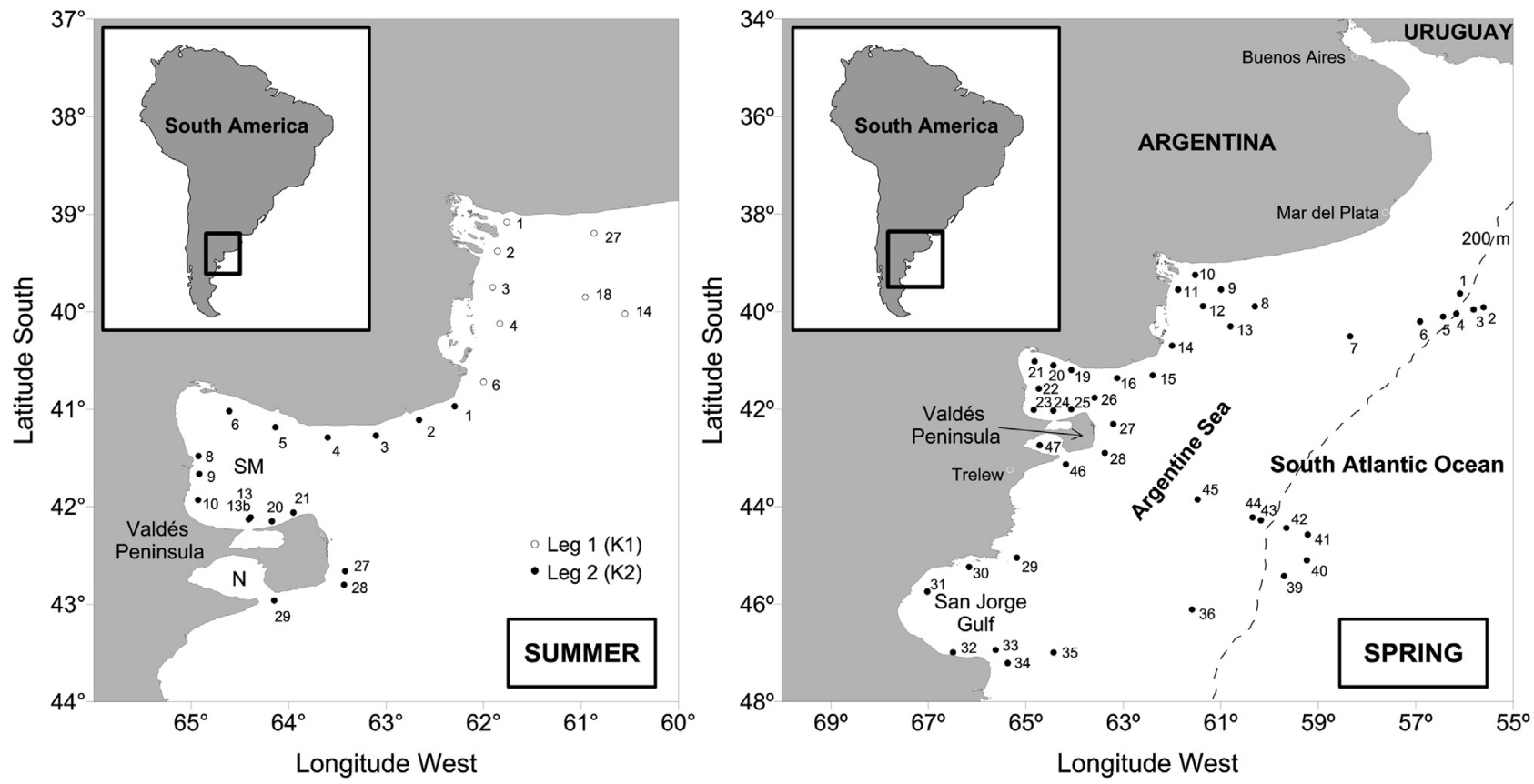

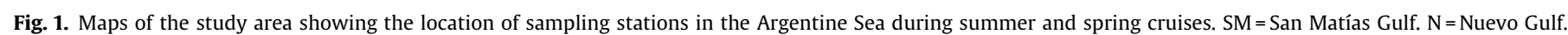


Niskin bottle samples were taken from 3 and $10 \mathrm{~m}$ depth and mixed at equal volume for determination of total plankton community composition and quantitative analyses. In addition, vertical net tows through the upper $20 \mathrm{~m}$ of the water column were conducted with a $20 \mu \mathrm{m}$-mesh Nitex net for both taxonomic and phycotoxin analysis. Each net haul concentrate was diluted up to $1 \mathrm{~L}$ with $0.2 \mu \mathrm{m}$-filtered seawater. An aliquot of $100 \mathrm{~mL}$ was fixed with Lugol's iodine solution for species identification and enumeration. The rest was sequentially filtered through Nitex mesh of 200, 50 and $20 \mu \mathrm{m}$ in PVC cylinders by gravity filtration and split into aliquots for toxin extraction. The particulate material retained on each mesh was re-suspended in $40 \mathrm{~mL}$ of filtered seawater and transferred into $50 \mathrm{~mL}$ centrifuge tubes. Pellets obtained by centrifugation were stored at $-20^{\circ} \mathrm{C}$ for later toxin analysis. Toxin results from fractions $20-50 \mu \mathrm{m}$ and $50-200 \mu \mathrm{m}$ were combined in a single value $(20-200 \mu \mathrm{m})$ throughout the manuscript and figures. In order to exclude the potential DA accumulation in large zooplankton (e.g., copepods), aliquots corresponding to the higher size fraction $(>200 \mu \mathrm{m})$ were not considered in this study.

\subsection{Phytoplankton taxonomic and quantitative analysis}

Net and Niskin bottle samples were analysed by a combination of light and electron microscopy methods to determine Pseudonitzschia species identity and cell abundance. The abundance (in cells $\mathrm{L}^{-1}$ ) of the genus Pseudo-nitzschia in samples collected by Niskin bottles was determined with a phase-contrast Leica DMIL LED inverted microscope according to the procedures described by Utermöhl (1958). Subsamples of $50 \mathrm{~mL}$ were settled for $24 \mathrm{~h}$ in a composite sedimentation chamber.

An aliquot of each net sample was washed with distilled water several times for desalting and then treated to remove organic material, following Prygiel and Coste (2000). Raw (untreated) and cleaned cell specimens were then mounted on permanent slides with Naphrax mounting medium according to Ferrario et al. (1995). Cleaned material from 16 samples, selected by the presence of potentially toxic Pseudo-nitzschia species after light microscopic examination of slides, was also mounted onto glass stubs or filtered onto $0.2 \mu \mathrm{m}$ polyamide or $2 \mu \mathrm{m}$ polycarbonate filters and sputtercoated with Au-Pd for scanning electron microscopy (SEM) analysis to confirm species identity. The SEM observations were carried out with a Jeol JSM-6360 LV and a FEI Quanta FEG 200 electron microscope.

Permanent slides were analysed under a phase-contrast Leica DM2500 microscope. In order to estimate the relative cell abundance of Pseudo-nitzschia species within the genus, all specimens present on the whole slide (average of 104 Pseudonitzschia specimens per slide) were enumerated at $1000 \times$. In samples with high Pseudo-nitzschia species cell densities, specimens were enumerated by examination of linear transects until at least 100 specimens were recorded.

Cell abundance of Pseudo-nitzschia species in net samples was determined by counting aliquots of $1 \mathrm{~mL}$ in Sedgewick-Rafter chambers with a phase-contrast Leica DMIL LED inverted microscope. These data served for semi-quantitative comparison of cell densities and toxin concentrations. Given the difficulty to identify most Pseudo-nitzchia species to species level in raw samples by light microscopy, only total Pseudo-nitzschia cell abundance was estimated at this stage. The detection limit was 1000 cells per net tow. Total Pseudo-nitzschia density, expressed per net tow (cells $\mathrm{NT}^{-1}$ ), was multiplied by the relative abundances estimated by the enumeration of permanent slides to obtain the abundance of different species.

\subsection{Toxin analysis}

Cell pellets from the plankton net tow size fractions were suspended in $500 \mu \mathrm{L}$ methanol, and subsequently homogenized with $0.9 \mathrm{~g}$ of lysing matrix $\mathrm{D}$ by reciprocal shaking at maximum speed $\left(6.5 \mathrm{~m} \mathrm{~s}^{-1}\right)$ for $45 \mathrm{~s}$ in a Bio101 FastPrep instrument (Thermo Savant, Illkirch, France). After homogenization, samples were centrifuged at $16,100 \mathrm{xg}$ at $4{ }^{\circ} \mathrm{C}$ for $15 \mathrm{~min}$. The supernatant was transferred to a spin-filter $(0.45 \mu \mathrm{m}$ pore-size, Millipore Ultrafree, Eschborn, Germany) and centrifuged for $30 \mathrm{~s}$ at $800 \mathrm{xg}$, followed by transfer to autosampler vials. Analysis of domoic acid was performed by liquid chromatography coupled to tandem mass spectrometry (LC-MS/MS), as described in Krock et al. (2008). Toxin concentrations are expressed as nanograms per net tow (ng $\mathrm{NT}^{-1}$ ). Detection limits were 4.9 and $6.6 \mathrm{ng} \mathrm{DA} \mathrm{NT}^{-1}$ for the summer and spring expeditions, respectively.

\subsection{Data analysis}

A non-parametric Spearman's correlation analysis was employed to determine correlations between Pseudo-nitzschia species abundance, DA concentration and environmental factors (temperature and salinity). Unidentified specimens corresponding to the Pseudo-nitzschia pseudodelicatissima species complex were considered as a single group for the correlation analysis.

\section{Results}

\subsection{Pseudo-nitzschia diversity}

Morphological analyses revealed the presence of $P$. australis, $P$. brasiliana Lundholm, Hasle and Fryxell, $P$. dolorosa Lundholm and Moestrup, P. fraudulenta, P. lineola (Cleve) Hasle, P. pungens, $P$. turgidula (Hustedt) Hasle and $P$. turgiduloides (Hasle) Hasle. Among these species, $P$. australis, $P$. brasiliana, $P$. fraudulenta, $P$. pungens and $P$. turgidula (Fig. 2) are usually considered as potentially domoic acid producers worldwide. Unidentified specimens corresponding to the Pseudo-nitzschia pseudodelicatissima species complex were also observed. The findings of $P$. brasiliana and $P$. dolorosa represent new records for the Argentine Sea, and thus a brief morphological description is provided here.

Valves of $P$. brasiliana were linear or linear-lanceolate, 16.7$42 \mu \mathrm{m}$ long and $2.0-2.5 \mu \mathrm{m}$ wide, with broadly rounded ends (Fig. 2G). Striae were present in the same number as fibulae (26 in $10 \mu \mathrm{m})$. There was no larger interspace in the central part of cell frustule.

Valves of $P$. dolorosa were lanceolate, $40-51.5 \mu \mathrm{m}$ long and 2.5$2.8 \mu \mathrm{m}$ wide, with round ends and presence of central interspace (Fig. 3A and B). Striae (33-36 in $10 \mu \mathrm{m})$ presented two rows of poroids (7-9 in $1 \mu \mathrm{m}$ ). Fibulae were less dense than striae (19-21 in $10 \mu \mathrm{m})$.

In addition, specimens with long and slender valves, 55-84 $\mu \mathrm{m}$ long and $1.5-2.5 \mu \mathrm{m}$ wide, were also detected. The presence of fibulae and the central interspace could usually be observed by phase contrast light microscopy. Under SEM, these specimens showed striae with only one row of poroids (Fig. 3C-E). The number of striae was $34-40$ in $10 \mu \mathrm{m}$ and fibulae $16-22$, delimiting a large central interspace. Poroids were disposed in numbers of 56 in $1 \mu \mathrm{m}$. The mantle was structured as the valve face, with height of two or three poroid widths. Bands and girdle details could not be observed. Given that neither transmission electron observations nor molecular analysis were carried out during this study, these specimens could only be assigned as part of the Pseudo-nitzschia pseudodelicatissima (Hasle) Hasle species complex sensu Lundholm et al. (2003). 

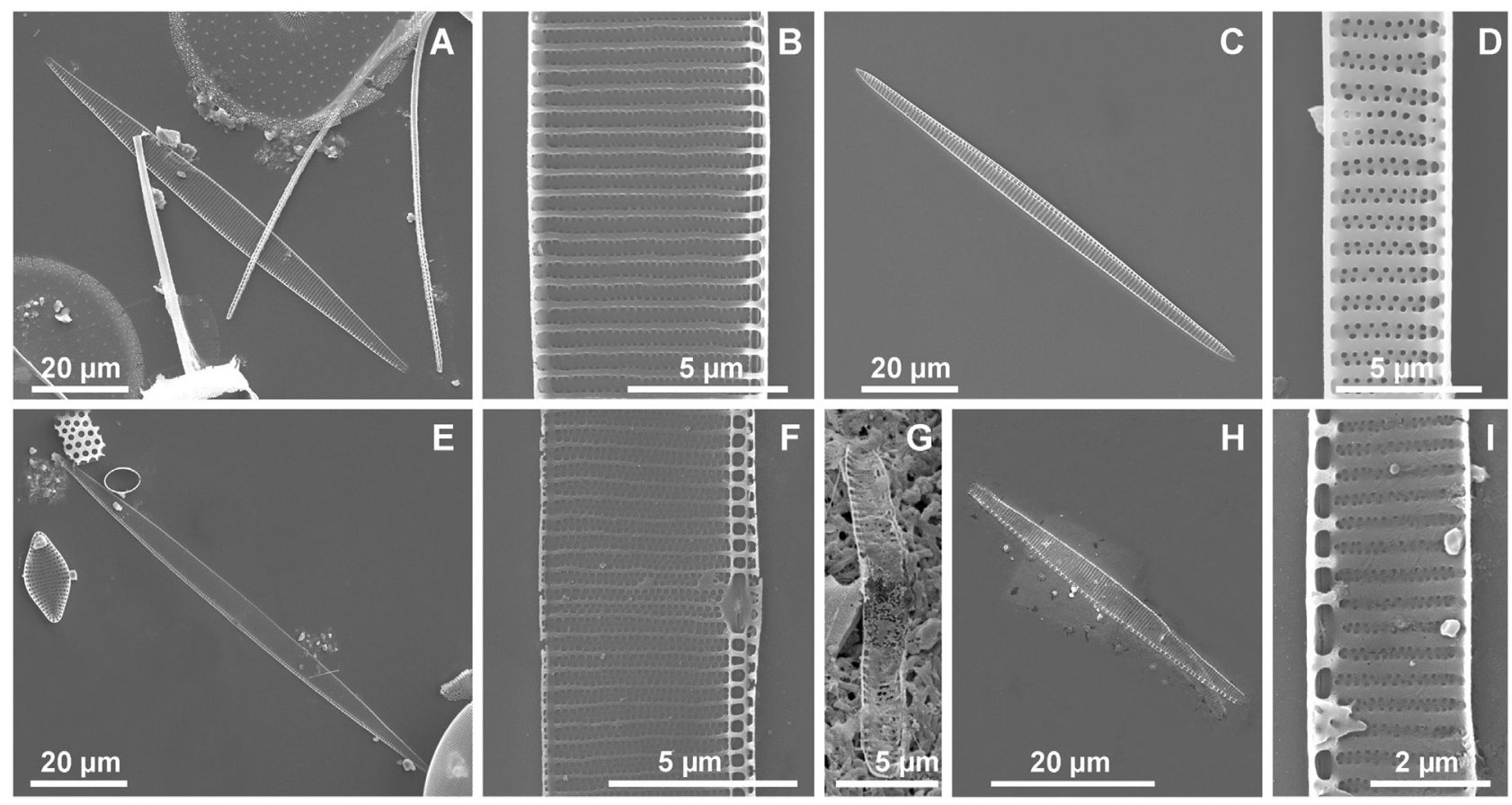

Fig. 2. Scanning electron (SEM) micrographs of potentially toxic Pseudo-nitzschia species observed from the Argentine Sea. (A and B): P. australis; (C and D) P. pungens; (E and F) P. fraudulenta; (G) P. brasiliana; (H and I) P. turgidula.

\subsection{Pseudo-nitzschia species composition of natural plankton populations}

\subsubsection{Summer expedition}

The genus Pseudo-nitzschia was observed in $70.8 \%$ of the Niskin bottle samples, with densities ranging between 80 and 13,840 cells $\mathrm{L}^{-1}$ (mean: $1.9 \times 10^{3}$ cells $\mathrm{L}^{-1} ; \mathrm{n}=17$ ) and accounting for $0.2-51.6 \%$ of total diatom cell densities, with an average contribution of $8.1 \%$ (Fig. 4). The highest Pseudo-nitzschia cell densities and highest contribution to diatom cell densities were observed around Valdés Peninsula (St 13-29 K2). In net samples, Pseudo-nitzschia cells were also observed at $70.8 \%$ of sampling stations, with densities ranging between $3 \times 10^{3}$ and $10.7 \times 10^{6}$ cells $\mathrm{NT}^{-1}$ (Fig. 5A). In fact, the density of Pseudo-nitzschia species in Niskin bottle and net samples showed a significant positive correlation $\left(r_{s}=0.72 ; \mathrm{p}<0.05\right)$.

Four Pseudo-nitzschia species were observed during this expedition: P. brasiliana, $P$. australis, $P$. fraudulenta, $P$. pungens and unidentified specimens of the $P$. pseudodelicatissima complex
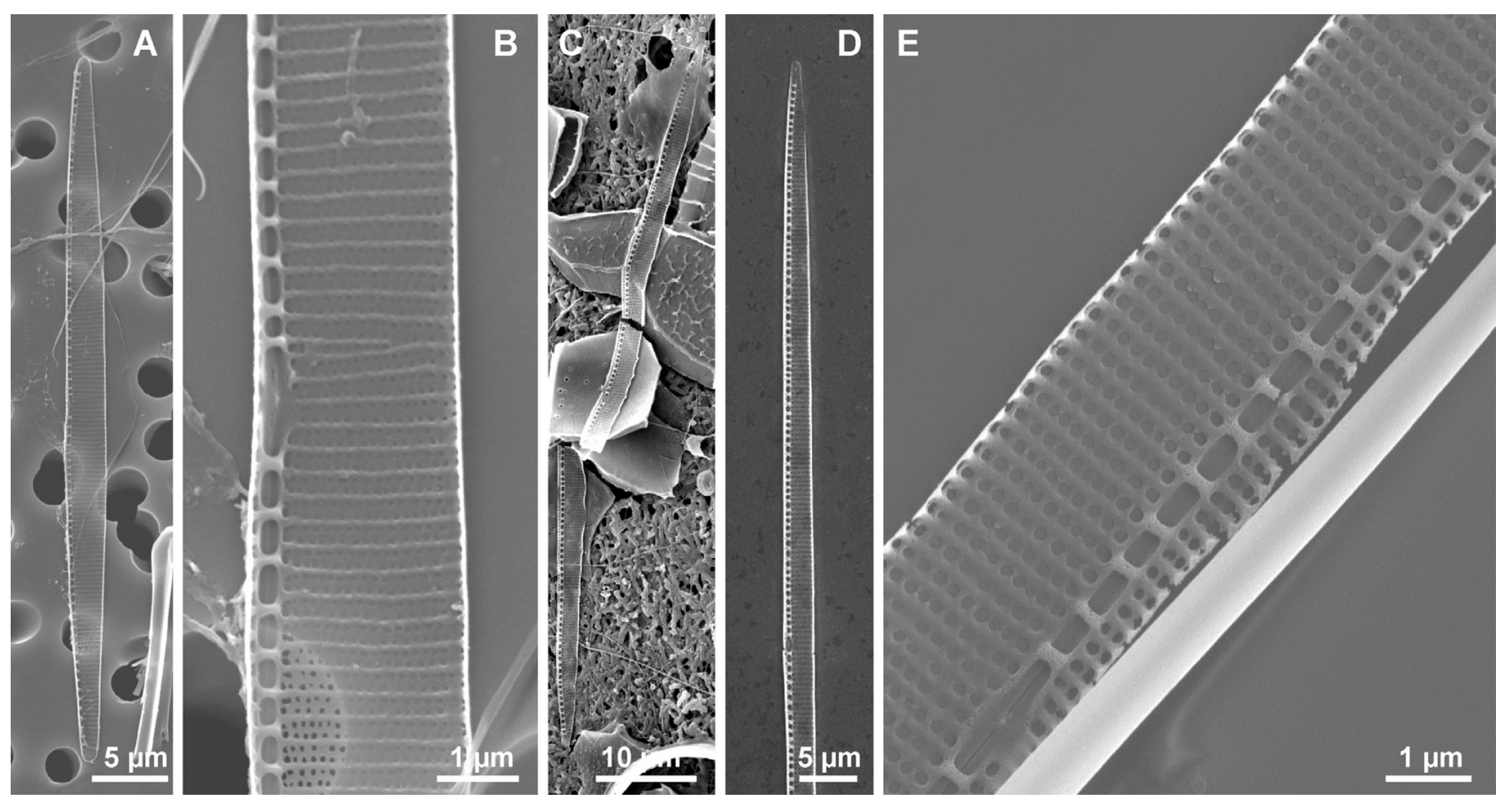

Fig. 3. Scanning electron (SEM) micrographs of other Pseudo-nitzschia species observed from the Argentine Sea. (A and B) P. dolorosa; (C-E) Specimens corresponding to the Pseudo-nitzschia pseudodelicatissima complex but not identified to species. 


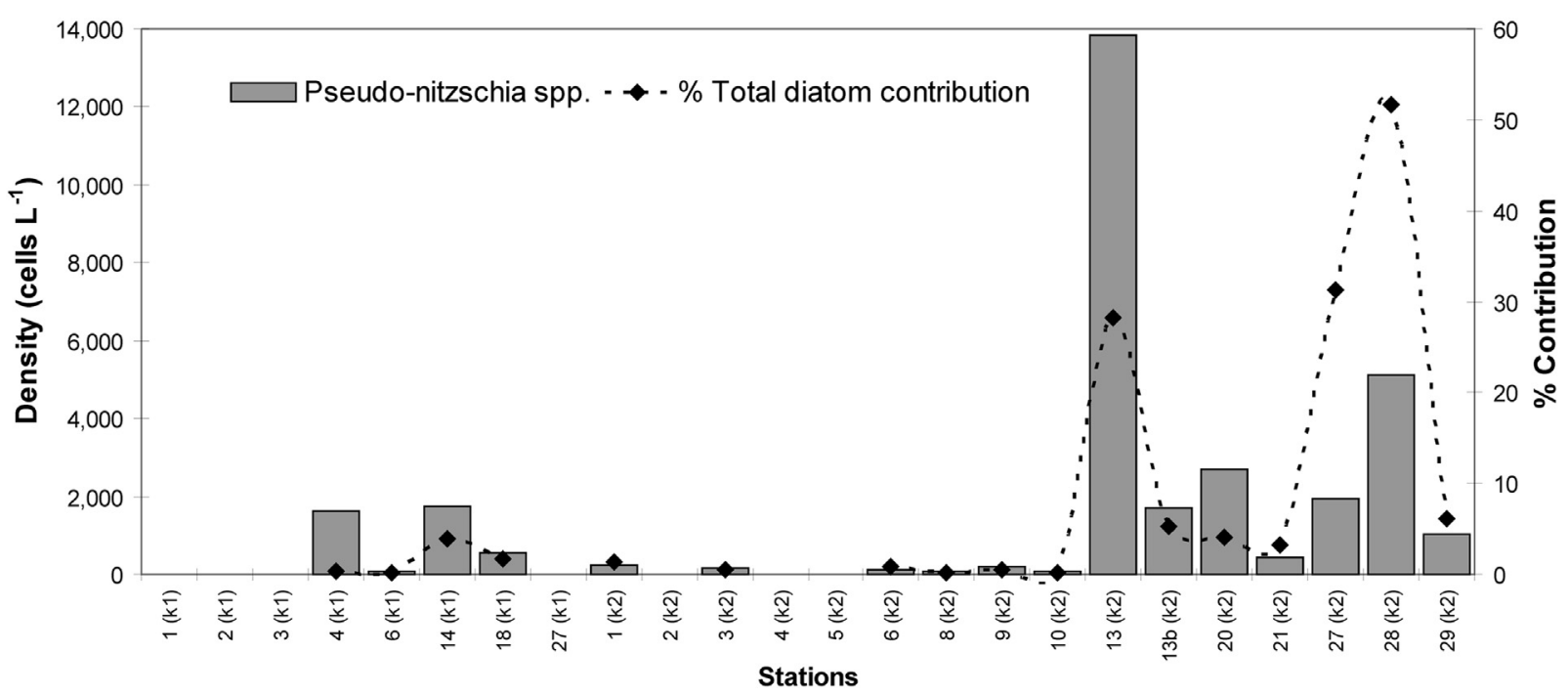

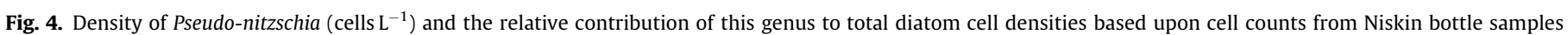
collected at surface waters during the summer expedition. $\mathrm{K} 1$ and $\mathrm{k} 2$ refers to different cruise legs.

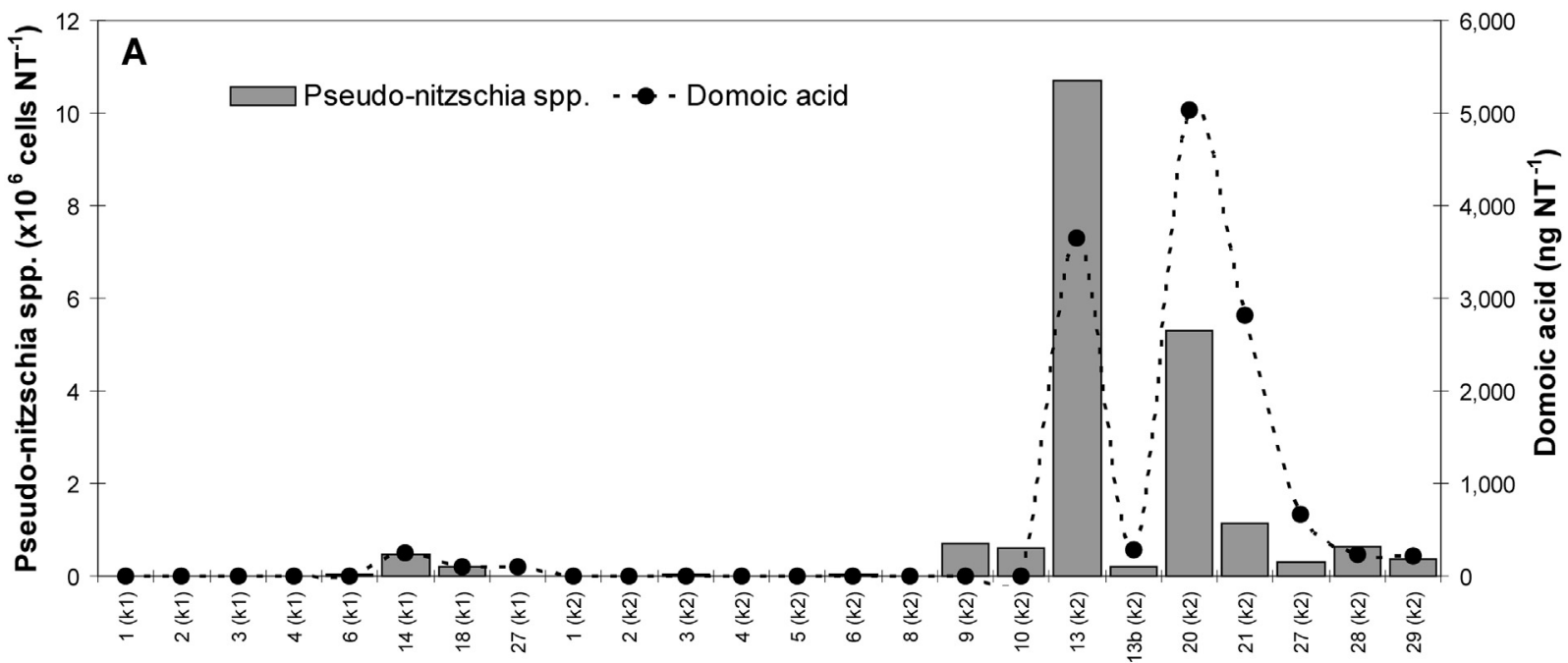

圆P. brasiliana $\square P$. australis $\square$ P. pungens $\square P$. fraudulenta 目P. pseudodelicatissima complex

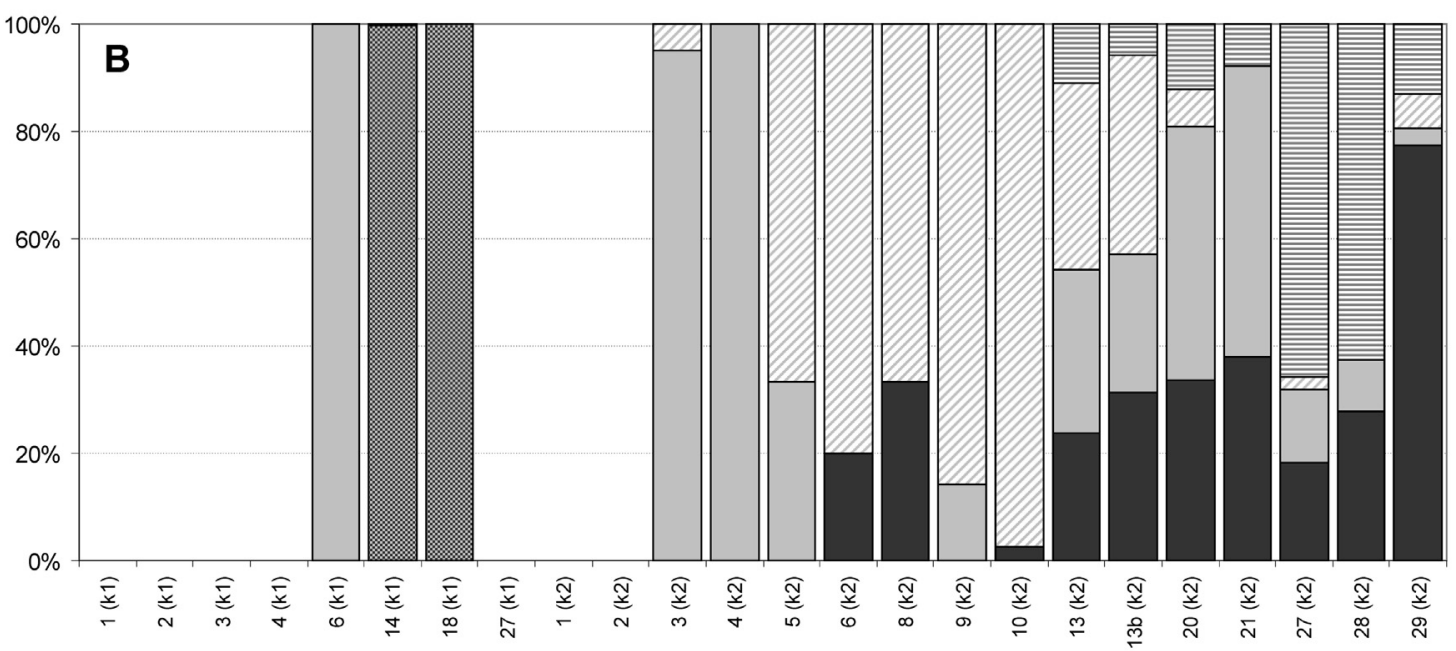

Stations

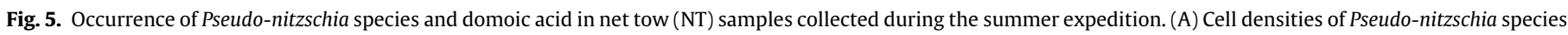
and concentration of domoic acid; (B) Relative cell abundance of Pseudo-nitzschia species. K1 and k2 refers to different cruise legs. 
were also found. The most commonly occurring species were $P$. pungens, $P$. fraudulenta and $P$. australis, represented, respectively, in $54.2,45.8$ and $41.7 \%$ of net samples. Among these Pseudo-nitzschia species, $P$. fraudulenta and $P$. pungens were the most abundant in seven and five samples, respectively (Fig. 5B). In addition, these two species reached high percentages in those samples with the highest Pseudo-nitzschia cell densities recorded along this expedition (i.e., St 13, 20 and 21). Likewise, P. brasiliana and the unidentified species of the $P$. pseudodelicatissima complex represented the highest percentage of Pseudo-nitzschia taxa in two samples each, whereas $P$. australis predominated in only one sample.

Domoic acid was detected in $41.7 \%$ of net samples, with concentrations between 96 and $5041 \mathrm{ng} \mathrm{NT}^{-1}$ (Fig. 5A). The highest DA concentrations were detected at St 13 and 20, which were also the stations where the highest cell densities of Pseudo-nitzschia species were found. In fact, DA concentrations and Pseudo-nitzschia species densities showed a significant positive correlation $\left(r_{s}=0.67 ; \mathrm{p}<0.05\right)$. Nevertheless, low DA concentration was recorded at St 27 (K1), but no Pseudo-nitzschia cells were detected in either Niskin bottle or phytoplankton net samples.

In the northern area $\left(\approx 39-41^{\circ} \mathrm{S}\right)$, low DA concentrations were detected together with the occurrence of $P$. brasiliana (St 14 and 18), which represented $>99 \%$ of total Pseudo-nitzschia cells at both stations (Fig. 5B). Estimate cellular DA content in these samples was $0.45-0.56 \mathrm{pg} \mathrm{cell}^{-1}$ if this species is considered as the unique DA source.

In the southern area, at St 13-29, south of San Matías Gulf and Valdés Peninsula, the DA concentrations were considerably higher (Fig. 5A). Domoic acid was detected in seven samples, in which the co-occurrence of $P$. australis, $P$. pungens and specimens of the $P$. pseudodelicatissima complex was always observed (Fig. 5). In addition, P. fraudulenta was also observed in five of those samples.

\subsubsection{Spring expedition}

The genus Pseudo-nitzschia was observed in $95.3 \%$ of the Niskin bottle samples, with densities ranging between 40 and $5.5 \times 10^{5}$ cells $\mathrm{L}^{-1}$ (mean: 72,113 cells $\mathrm{L}^{-1} ; \mathrm{n}=41$ ), and accounting for 0.003 to $99.3 \%$ of total diatom cell densities, with an average contribution of $32.0 \%$ (Fig. 6). The highest Pseudo-nitzschia densities $\left(>2.5 \times 10^{5}\right.$ cells $\mathrm{L}^{-1}$ ) were recorded in San Matías Gulf (St 19-24). The genus was mainly represented by $P$. fraudulenta, which accounted for
86.8-97.4\% of total diatom density. In net samples, the genus Pseudo-nitzschia was observed at $86.0 \%$ of stations, with densities ranging between 40 and $98.6 \times 10^{6}$ cells $\mathrm{NT}^{-1}$ (Fig. 7A). Densities estimated in bottle and net samples showed a positive significant correlation $\left(r_{s}=0.77 ; \mathrm{p}<0.05\right)$.

At least eight Pseudo-nitzschia species were observed during this expedition: P. australis, $P$. brasiliana, . dolorosa, . fraudulenta, $P$. lineola, $P$. pungens, $P$. turgidula, $P$. turgiduloides and these were accompanied by unidentified specimens of the $P$. pseudodelicatissima complex. The most commonly occurring species were $P$. fraudulenta and $P$. pungens, present respectively in 79.1 and $74.4 \%$ of all net samples examined. In addition, $P$. fraudulenta was the most abundant species found during this expedition (Fig. 7B), reaching densities of up to $10^{5}$ cells $\mathrm{L}^{-1}$ and representing an average of $74.1 \%$ $(\mathrm{n}=34)$ of total Pseudo-nitzschia cells. By contrast, P. pungens, which also had a widespread distribution, represented an average of $10.1 \%(n=32)$ of the genus cell density.

Domoic acid was detected in $20.9 \%$ of net samples, with concentrations between 69 and 54,805 ng NT ${ }^{-1}$ (Fig. 7A). High concentrations were found at only two sampling stations located in shelf waters south of Valdés Península (St. 46) and in Nuevo Gulf (St. 47), where Pseudo-nitzschia cell densities were relatively low. By contrast, at stations 19-24, where high Pseudo-nitzschia cell densities were recorded, DA was almost completely absent (Fig. 7A). In fact, DA concentrations and Pseudo-nitzschia densities showed only a weak and non-significant correlation for the spring expedition $\left(r_{s}=0.27 ; \mathrm{p}>0.05\right)$.

At stations 46 and 47, with high DA concentrations, Pseudonitzchia cell densities were dominated by P. australis (Fig. 7), which reached densities of up to $1.7 \times 10^{6}$ cells $\mathrm{NT}^{-1}$. Pseudo-nitzschia australis was observed in other four samples during this expedition but at low densities. At St. 42, where low DA values were also recorded, the species density reached $5.6 \times 10^{3}$ cells $\mathrm{NT}^{-1}$. In the other three samples (St 43-45), densities were lower than 100 cells $\mathrm{NT}^{-1}$ and DA was not detected.

Rather low DA values were measured from other stations, but no clear association with a single Pseudo-nitzschia species could be detected. For example, at St 1, located in northern shelf-break waters, relatively low DA values $\left(281 \mathrm{ng} \mathrm{NT}^{-1}\right)$ were detected. At this sampling station, Pseudo-nitzschia cells were dominated by specimens of the $P$. pseudodelicatissima complex, but $P$. dolorosa, $P$. pungens and $P$. fraudulenta were also observed. At St 3-5, in which a

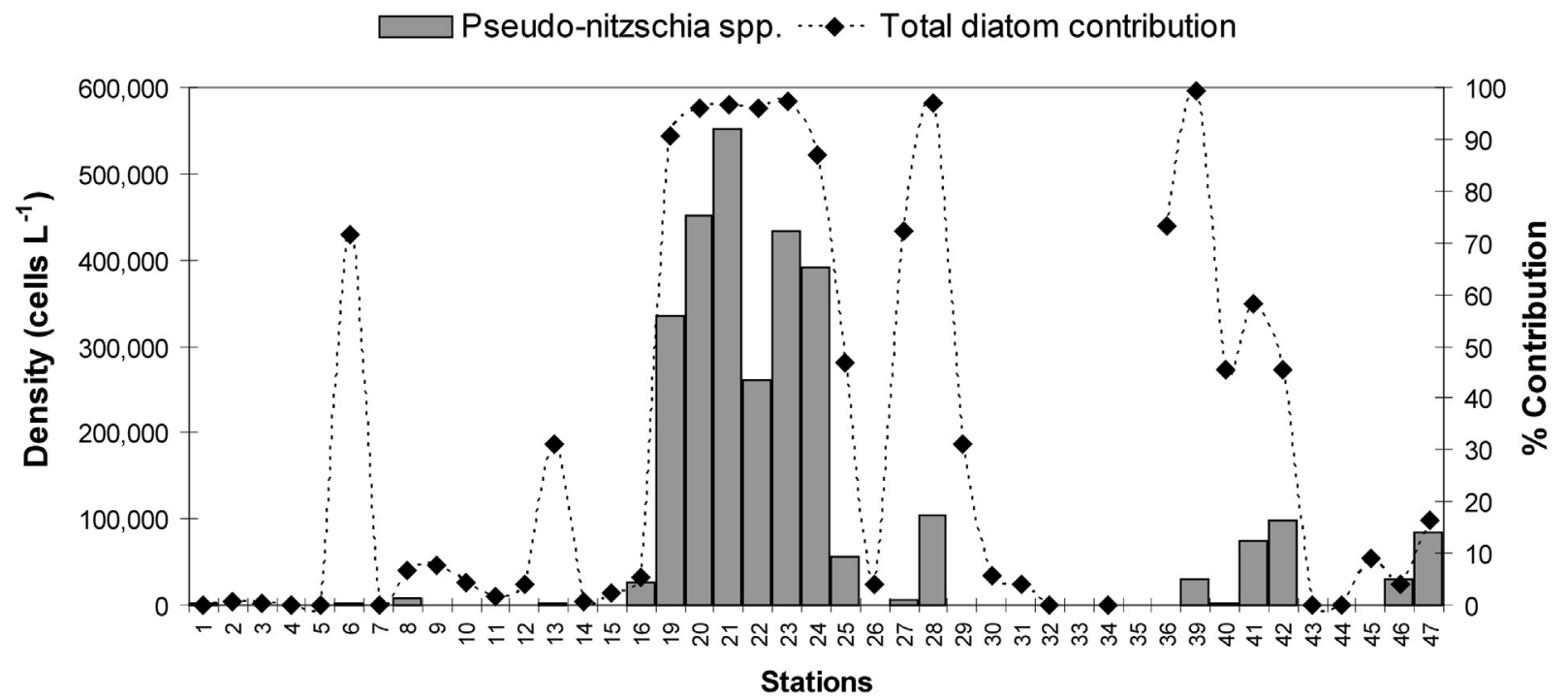

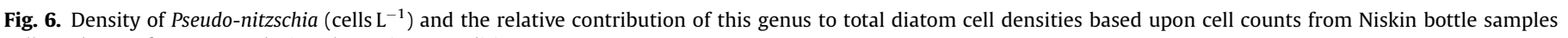
collected at surface waters during the spring expedition. 


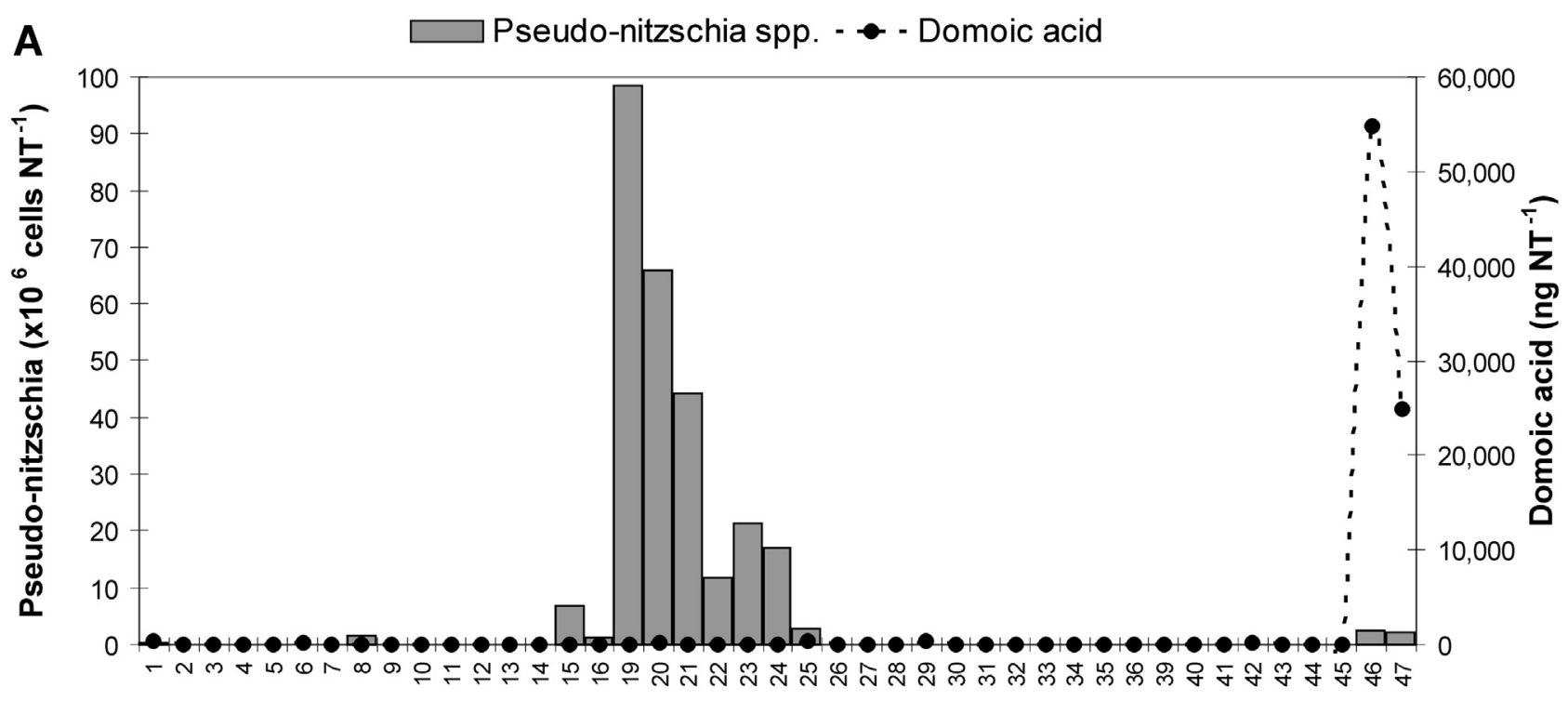

B

\begin{tabular}{|c|c|c|}
\hline 圆P. brasiliana & $\square P$. australis & $\square P$. fraudulenta \\
\hline$\square P$. pungens & 目P.pseudodelicatissima complex & $\square P$. dolorosa \\
\hline$\square P$. turgidula & $\mathbf{\$} P$. lineola & 图P. turgiduloides \\
\hline
\end{tabular}

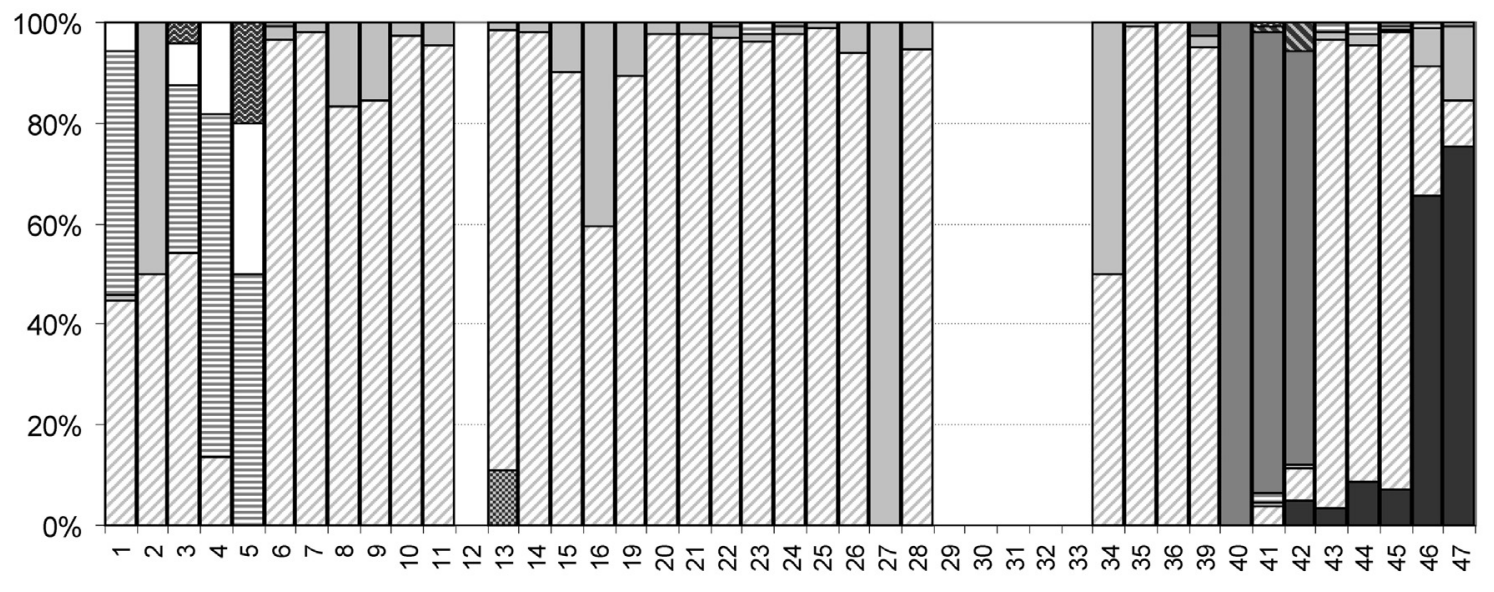

Stations

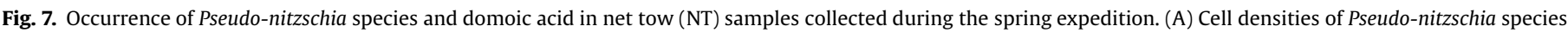
and concentration of domoic acid; (B) Relative cell abundance of Pseudo-nitzschia species.

large contribution of specimens of the $P$. pseudodelicatissima complex was observed, DA was not detected. At stations 6, 20 and 25, low DA values were recorded (116-345 $\mathrm{ng} \mathrm{NT}^{-1}$ ). In these samples, $P$. fraudulenta was the dominant Pseudo-nitzschia species, accounting for $96.5-99.0 \%$ of total cells and reaching densities from $8.8 \times 10^{4}$ to $6.4 \times 10^{6}$ cells $\mathrm{NT}^{-1}$. This finding does not match with that for several other samples in which $P$. fraudulenta reached even higher densities (up to $9.9 \times 10^{6}$ cells $\mathrm{NT}^{-1}$ ) but no DA was detected (Fig. 7). Very low DA values (69 $\mathrm{ng} \mathrm{NT}^{-1}$ ) were detected at St 27, from which $P$. pungens was the only Pseudo-nitzschia species recorded. Finally, at St 29, DA values of $323 \mathrm{ng} \mathrm{NT}^{-1}$ were detected, but no Pseudo-nitzschia cells were observed in net samples.

\subsection{Correlation analysis}

Spearman's correlation analysis showed that DA concentration was significantly correlated with cell densities of $P$. australis $\left(r_{s}=0.55\right)$, . pungens $\left(r_{s}=0.43\right)$ and $P$. pseudodelicatissima complex $\left(r_{s}=0.47\right) \quad($ Table 1$)$. Regarding the relationships between
Pseudo-nitzschia species and environmental factors, the correlation of $P$. fraudulenta with temperature was significantly positive $\left(r_{s}=0.30\right)$ and significantly negative $\left(r_{s}=-0.37\right)$ for $P$. australis. In addition, densities of $P$. fraudulenta $\left(r_{s}=0.62\right)$ and $P$. pungens $\left(r_{s}=0.60\right)$ were positively correlated with salinity. No significant

Table 1

Spearman rank correlation coefficients for Pseudo-nitzschia species, domoic acid (DA), temperature (Temp) and salinity (Sal).

\begin{tabular}{llll}
\hline Species & DA & Temp & Sal \\
\hline P. brasiliana & 0.13 & -0.07 & -0.16 \\
P. australis & $0.55^{* *}$ & $-0.37^{* *}$ & 0.01 \\
P. fraudulenta & 0.17 & $0.30^{* *}$ & $0.62^{* *}$ \\
P. pungens & $0.43^{* *}$ & 0.15 & $0.50^{* *}$ \\
P. pseudodelicatissima complex & $0.47^{* *}$ & -0.20 & 0.22 \\
P. dolorosa & -0.02 & -0.10 & 0.07 \\
P. turgidula & -0.07 & -0.02 & 0.25 \\
P. lineola & 0.06 & -0.05 & 0.16 \\
P. turgiduloides & -0.13 & -0.03 & 0.14 \\
\hline
\end{tabular}

${ }^{* * *} p<0.05, n=67$. 
correlations between DA concentration and temperature or salinity were found $\left(r_{s}=-0.23\right.$ and -0.13 , respectively; $\left.\mathrm{p}>0.05\right)$.

\section{Discussion}

The number of described Pseudo-nitzschia species, as well as the number of confirmed DA producers in culture, has notably increased in the last few years (e.g., Lelong et al., 2012; Lim et al., 2013; Orive et al., 2013; Teng et al., 2016; Percopo et al., 2016). By contrast, the worldwide distribution of most of these species and their toxicity in natural populations is still poorly known. In the present work, we focused on the occurrence of Pseudo-nitzschia species and domoic acid throughout the Argentine Sea. In this region, DA has been previously detected but the identity of the planktonic producers remains unclear.

The genus Pseudo-nitzschia was widespread during this study, observed in $\approx 80 \%$ of all examined samples with concentrations up to $5.5 \times 10^{6}$ cells $\mathrm{L}^{-1}$. By contrast, domoic acid was detected in only $\approx 28 \%$ of samples, which indicates that not all Pseudo-nitzschia species are consistently toxigenic in the Argentine Sea. This is not surprising given that only five of the nine identified taxa, $P$. australis, $P$. brasiliana, $P$. fraudulenta, $P$. pungens and $P$. turgidula, are considered as potentially toxic species (Lelong et al., 2012). However, these potentially toxic species represented an average of 96\% of total Pseudo-nitzschia density. It is therefore possible that some of these species mentioned as DA producers in other parts of the world are represented by non-toxigenic genotypes in the Argentine Sea, or produce DA only under specific environmental conditions, such as nutrient depletion, elevated irradiance and $\mathrm{pH}$ (reviewed in Lelong et al., 2012) or is inducible by exposure to copepod grazing (Tammilehto et al., 2015).

Previous studies have revealed that numerous species of the genus Pseudo-nitzschia can usually be found in the Argentine Sea (Negri and Inza, 1998; Ferrario et al., 1999; Almandoz et al., 2007). Considering the first report of two species in the present study, the total number of Pseudo-nitzschia species found in the Argentine Sea has been raised to 13 (Table 2). This number is based only on detailed morphological examination of field specimens and no molecular approaches have yet been applied to examine species diversity. Given that a great number of new cryptic or pseudocryptic species have been described in the last 20 years, species richness in the Argentine Sea could even be considerably higher.

The usual co-occurrence of more than one (and up to five) Pseudo-nitzschia species in field samples makes it difficult if not impossible to associate DA production to individual species. Nevertheless, $P$. australis showed the highest correlation with DA concentration, followed by the complex P. pseudodelicatissima and then $P$. pungens, suggesting the importance of the former species as

\section{Table 2}

List of Pseudo-nitzschia species recorded from the Argentine Sea, including first reports from the present study.

\begin{tabular}{ll}
\hline Species & Reference \\
\hline P. americana & Almandoz (2008) \\
P. australis & Negri and Inza (1998) \\
P. brasiliana & this study, first report \\
P. dolorosa & this study, first report \\
P. fraudulenta & Negri and Inza (1998) \\
P. heimii & Almandoz et al. (2007) \\
P. lineola & Almandoz et al. (2007) \\
P. multiseries & Ferrario et al. (1999) \\
P. pseudodelicatissima complex & Ferrario et al. (1999) \\
P. pungens & Negri and Inza (1998) \\
P. subcurvata & Almandoz et al. (2007) \\
P. turgidula & Negri and Inza (1998) \\
P. turgiduloides & Almandoz et al. (2007) \\
\hline
\end{tabular}

a Identification not confirmed by electron microscopy. a major DA producer in the Argentine Sea. Considering both cruises, DA was detected in all stations where $P$. australis was present at densities higher than 50,000 cells NT ${ }^{-1}$. By contrast, high concentrations $\left(>500,000\right.$ cells $\left.\mathrm{NT}^{-1}\right)$ of $P$. pungens and the $P$. pseudodelicatissima complex were found in samples without detectable DA.

The key role of $P$. australis in the global production and distribution of DA has been confirmed in many studies. The production of DA by field populations of $P$. australis was first confirmed in Monterey Bay, California (USA) in 1991, during an ASP outbreak that caused massive deaths of pelicans (Pelecanus occidentalis) and cormorants (Phalacrocorax penicillatus) (Fritz et al., 1992; Garrison et al., 1992). Since then, numerous studies have confirmed DA production of this species in culture, as well as its association with poisoning episodes in marine birds and mammals (e.g., Míguez et al., 1996; Sierra-Beltrán et al., 1997; Fraga et al., 1998; Scholin et al., 2000; Cusack et al., 2002; Schnetzer et al., 2007; Fire et al., 2010; McCabe et al., 2016).

In Argentina, DA was first recorded in July 2000 from continental shelf waters next to the city of Mar del Plata $\left(\approx 38^{\circ} \mathrm{S}\right)$. At that time, during a bloom of Pseudo-nitzschia australis, DA was detected in phytoplankton, mussels (Mytilus edulis) and anchovies (Engraulis anchoita) (Negri et al., 2004). Moreover, DA was detected in phytoplankton samples from San Jorge Gulf, associated with the presence of both $P$. australis and $P$. pungens (Krock et al., 2015). In our study, the association of DA and high cells densities of $P$. australis was mainly evident in shelf waters south of Valdés Península and in Nuevo Gulf during spring. Assuming $P$. australis as the only DA producer in these samples, cellular DA content was $14.6-32.3 \mathrm{pgcell}^{-1}$, whereas if total Pseudo-nitzschia cells are considered these cell quotas would be reduced to $11.0-21.2 \mathrm{pgcell}^{-1}$. In either case, these quotas represent the higher values observed during our study and are in the range of the highest DA cell content measured in $P$. australis cultures (22, 27 and 37 pg cell $^{-1}$ ) by Guannel et al. (2011), Cusack et al. (2002) and Garrison et al. (1992), respectively.

Pseudo-nitzschia fraudulenta, together with $P$. pungens, was the most commonly observed species during this study. In addition, it bloomed in San Matías Gulf (St 19-24) during spring, accounting for more than $95 \%$ of total diatom abundances. However, only low DA values were detected in two of the seven samples with high densities of $P$. fraudulenta $\left(\approx 50,000-500,000\right.$ cells $\left.\mathrm{L}^{-1}\right)$. This suggests that this species may be only weakly toxigenic in the Argentine Sea, as was previously found in New Zealand coastal waters (Rhodes et al., 1998a, 1998b). The DA cell quotas estimated from the two samples in which DA was detected together with a predominance of $P$. fraudulenta ( $\approx 98 \%$ of total Pseudo-nitzschia) were 0.002 and $0.120 \mathrm{pg} \mathrm{cell}^{-1}$. These values are comparable to DA cell quotas obtained in cultures of $P$. fraudulenta by Rhodes et al. (1998a,b) (maximum 0.03 pg cell $^{-1}$ ) and Thessen et al. (2009) (maximum $0.16 \mathrm{pg}$ cell $^{-1}$ ). Despite these low toxin levels, DA has been previously detected in phytoplankton net samples (up to $6.6 \mu \mathrm{g} \mathrm{L}^{-1}$ ) collected in San José Gulf and Nuevo Gulf, coinciding with high cell densities of $P$. fraudulenta (Sastre et al., 2007). During the period when DA was detected, Sastre et al. (2007) observed $P$. fraudulenta at densities up to 24,200 cells $\mathrm{L}^{-1}$ in a period of strong nutrient depletion that reduced nitrate and silicate concentration to below detection limits. This is consistent with the finding that DA production by $P$. fraudulenta notably increases under silicatelimited conditions (Tatters et al., 2012).

Pseudo-nitzschia brasiliana, a known warm water species, has been observed in Brazil (Sepetiba Bay), Gulf of Panama, Gulf of Mexico, Gulf of California, Vietnam, Indonesia, Thailand and South Korea (Lundholm et al., 2002), and more recently also in Spain (Quijano-Scheggia et al., 2005), China (Li et al., 2010), Tunisia (Sahraoui et al., 2011) and Malaysia (Lim et al., 2012a,b). In the 
present study, $P$. brasiliana was recorded for the first time in the Argentine Sea, extending its known worldwide distribution southwards. This species was only observed in a few samples collected in the northern part $\left(\approx 39-40^{\circ} \mathrm{S}\right)$ of both sampling expeditions, at seawater temperatures around $13^{\circ} \mathrm{C}$ (spring) and $16^{\circ} \mathrm{C}$ (summer). During summer, when it reached higher densities, it was associated with DA occurrence, at estimated cell quotas of $0.45-0.56 \mathrm{pg} \mathrm{cell}^{-1}$. This is an interesting finding because the first toxin analyses of strains of $P$. brasiliana isolated from Sepetiba Bay (Brazil) did not detect the presence of DA (Lundholm et al., 2002). The lack of DA production was then confirmed in several strains isolated from the Mediterranean Sea (Quijano-Scheggia et al., 2010), south-eastern coast of China (Wang et al., 2012) and South China Sea of Malaysian Borneo (Lim et al., 2012a). Nevertheless, the toxigenicity of $P$. brasiliana was detected by Sahraoui et al. (2011), based upon the analysis of strains isolated from Bizerte Lagoon, Tunisia. In addition, the same authors also associated the occurrence of DA in field samples with the presence of $P$. brasiliana (Sahraoui et al., 2012). Thus, our current results agree with the recent findings of $P$. brasiliana as a DA producer. The estimated cell quotas of $0.45-0.56 \mathrm{pg} \mathrm{cell}^{-1}$ in field samples are higher than those previously detected in culture $\left(8.9 \mathrm{fg} \mathrm{cell}^{-1}\right)$ by Sahraoui et al. (2011), but represent low values when compared with other toxigenic Pseudo-nitzschia species (Trainer et al., 2012).

Pseudo-nitzschia turgidula, another potentially toxic species found in this study, showed a restricted distribution, being confined to colder $\left(\approx 7-8^{\circ} \mathrm{C}\right)$ southern shelf-break waters sampled during spring, which is in accordance with previous results in the Argentine Sea (Almandoz et al., 2007). Toxigenic strains of $P$. turgidula have been isolated in New Zealand and at Ocean Station PAPA $\left(50^{\circ} \mathrm{N}, 145^{\circ} \mathrm{W}\right)$ in the north-eastern Pacific, but they presented only low DA cell quotas $\left(5 \times 10^{-6}\right.$ to $\left.0.03 \mathrm{pg} \mathrm{cell}^{-1}\right)$ (Rhodes et al., 1998b; Trick et al., 2010). During our study, P. turgidula was observed in low cell densities and its distribution was not associated with DA occurrence. However, intense blooms of this species ( $u p$ to $3.3 \times 10^{6}$ cells $\mathrm{L}^{-1}$ ) have been found in northern shelf waters of the Argentine sea by Negri and Inza (1998), although no DA analyses were carried out during this bloom.

Pseudo-nitzschia dolorosa is a recently described species (Lundholm et al., 2006), which morphologically resembles $P$. turgidula. Both species can be mainly differentiated by examination of the number of striae and fibulae, which usually requires analysis by electron microscopy. Besides its original description, which confirmed its occurrence in Europe and Monterey Bay, California (Lundholm et al., 2006), it was also mentioned in a few studies carried out in the Drake Passage (Ferrario et al., 2004), northeast subarctic Pacific (Marchetti et al., 2008), the coasts of Portugal (Churro et al., 2009) and Malaysian Borneo (Lim et al., 2012a). In our study, it was confined to northern shelf-break waters sampled during spring, with temperatures of $8.1-9.7^{\circ} \mathrm{C}$ and salinities from 33.7 to 33.9 . During its previous finding in the Drake Passage (south of South America), it was observed in very low densities at water temperatures of $6.4^{\circ} \mathrm{C}$ and salinity of 34.0 (Ferrario et al., 2004).

The finding of DA in two samples in which Pseudo-nitzschia cells were not detected could be interpreted in different ways. First, the fact that only low levels of DA were detected, in both samples from summer and spring expeditions, respectively, could indicate that even if Pseudo-nitzschia cells were present, they were at densities below the detection limits of microscopic analysis. Second, although Pseudo-nitzschia species are considered to be by far the major DA producing diatoms, other species, such as Halamphora coffeiformis (Agardh) Levkov (previously known as Amphora coffeaeformis), Nitzschia navis-varingica (Lundholm and Moestrup, 2000; Kotaki et al., 2004; Romero et al., 2011; Tan et al., 2016) and $N$. bizertensis (Smida et al., 2014) have also been found to produce
DA. In any case, these benthic species are mainly found in brackish waters and were not detected in the present study in the Argentine Sea. Finally, DA could have been accumulated in zooplankton feeding on toxic Pseudo-nitzschia (Tester et al., 2001; Maneiro et al., 2005), such that intact diatom cells were no longer identifiable. Thus, even when plankton samples were pre-filtered through a $200 \mu \mathrm{m}$ mesh to remove large zooplankton before toxin analysis, the presence of DA accumulated in early life stages of zooplankton, their eggs or fecal pellets cannot be excluded.

Mariculture production in Argentina is an increasing activity with great future potential, given the large extension of its coast line (Kapetzki et al., 2013). Currently, there are several shellfish harvesting areas and also some shellfish culture sites, mainly located in the North Patagonian gulfs (RMCP, 2013). The wide distribution of several potentially toxic Pseudo-nitzschia species and particularly $P$. australis in Argentina, from northern waters of the Buenos Aires Province to southern waters of the Beagle Channel (e.g. Almandoz et al., 2007, 2011), could represent a potential risk for DA accumulation in shellfish. It is expected that the information here provided on the association of Pseudonitzschia species and DA occurrence provides a useful dataset to future monitoring programs.

\section{Conclusions}

Despite the wide distribution of Pseudo-nitzschia species observed in the Argentine Sea during spring and summer, the occurrence of DA was confined to a low percentage of samples. From the at least nine Pseudo-nitzschia species found throughout this study, DA occurrence was mainly associated with the presence of $P$. australis. By contrast, other potentially toxic species, such as $P$. fraudulenta, $P$. pungens and $P$. turgidula did not show a clear association with DA or showed low toxin levels. The complete biogeographical association of toxin production and species composition remains unresolved for the Argentine Sea, and additional field and culture studies are required to elucidate the pattern of DA production in this region.

\section{Acknowledgments}

We thank Sebastian Göller (AWI) for plankton sampling and processing during Expedition 2 and Wolfgang Drebing (AWI) for sample extraction and toxin measurements by LC-MS/MS. We extend our gratitude to Patricia Sarmiento and Friedel Hinz for the SEM services of Museo de La Plata and the Hustedt Collection, AWI, respectively. In addition, the friendly reception and support of the 2012 crew of the $R / V$ Puerto Deseado (CONICET-MINDEF, Argentina) and the 2013 crew of the $R / V$ Bernardo Houssay (Prefectura Naval Argentina) are gratefully acknowledged. This work was supported by PIP 0122 (CONICET) and PICT 0576 (ANPCyT) grants, the European Commission under the 7th Framework Programme through the Action-IMCONet (FP7 IRSES, Action No. 319718), the Helmholtz-Gemeinschaft Deutscher Forschungszentren through the research programme PACES of the Alfred Wegener InstitutHelmholtz Zentrum für Polar- und Meeresforschung, and the binational project MINCyT-BMBF (AL/11/03-ARG 11/021).[SS]

\section{References}

Almandoz, G.O., Ferrario, M.E., Ferreyra, G.A., Schloss, I.R., Esteves, J.L., Paparazzo, F. E., 2007. The genus Pseudo-nitzschia (Bacillariophyceae) in continental shelf waters of Argentina (Southwestern Atlantic Ocean, 38-55(S). Harmful Algae 6, 93-103.

Almandoz, G.O., Hernando, M., Ferreyra, G.A., Schloss, I.R., Ferrario, M.E., 2011. Seasonal phytoplankton dynamics in extreme southern South America (Beagle Channel, Argentina). J. Sea Res. 66, 47-57. 
Almandoz, G.O., 2008. Distribución geográfica y variación interanual del género Pseudo-nitzschia (Bacillariophyceae) en aguas de la plataforma del Mar Argentino y Antártida. PhD Thesis. University of La Plata, La Plata.

Cadaillón, A.M., 2012. Floraciones algales nocivas y ficotoxinas en fitoplancton y zooplancton de los golfos Nuevo y San José. Lic. Thesis. Universidad Nacional de la Patagonia, San Juan Bosco, pp. 172.

Churro, C.I., Carreira, C.C., Rodrigues, F.J., Craveiro, S.C., Calado, A.J., Casteleyn, G., Lundholm, N., 2009. Diversity and abundance of potentially toxic Pseudonitzschia peragallo in Aveiro coastal lagoon Portugal and description of a new variety, P. pungens var. aveirensis var. nov. Diatom. Res. 24, 35-62.

Cusack, C.K., Bates, S.S., Quilliam, M.A., Patching, J.W., Raine, R., 2002. Confirmation of domoic acid production by Pseudo-nitzschia australis (Bacillariophyceae) isolated from Irish waters. J. Phycol. 38, 1106-1112.

D'Agostino, V.C., Hoffmeyer, M.S., Almandoz, G.O., Sastre, V., Degrati, M., 2015. Potentially toxic Pseudo-nitzschia species in plankton and fecal samples of Eubalaena australis from Península Valdés calving ground, Argentina. J. Sea Res. 106, 39-43.

Ferrario, M.E. Sar, E.A. Sala, S., 1995. Metodología básica para el estudio del fitoplancton con espacial referencia a las diatomeas. In: Alveal, K., Ferrario, M.E., Oliveira, E.C., Sar, E.A. (Eds.), Manual de Métodos Ficológicos. Universidad de Concepción, Editora A, Pinto, Chile, pp. 1-23.

Ferrario, M.E., Sar, E.A., Castaños, C., Hinz, F., 1999. Potentially toxic species of the diatom genus Pseudo-nitzschia in Argentinian coastal waters. Nova Hedwigia 68, 131-147.

Ferrario, M.E., Sar, E.A., Sala, S., 2002. Diatomeas potencialmente toxígenas del Cono Sur Americano. In: Sar, E.A., Ferrario, M.E., Reguera, B. (Eds.), Floraciones algales nocivas en el Cono Sur Americano. Instituto Español Oceanográfico de Madrid, Vigo, pp. 167-194.

Ferrario, M., Licea, S., Balestrini, C.F., Ferreyra, G., 2004. Species of Pseudo-nitzschia in the Drake Passage (54-61 ${ }^{\circ} \mathrm{S}$ to $\left.46-64^{\circ} \mathrm{W}\right)$. In: Steidinger, K.A., Landsberg, J.H., Tomas, C.R., Vargo, G.A. (Eds.), Harmful Algae 2002. Florida Fish and Wildlife Conservation Commission, Florida Institute of Oceanography, and Intergovernmental Oceanographic Commission of UNESCO, Paris, pp. 434-436.

Fire, S.E., Van Dolah, F.M., 2012. Marine biotoxins: emergence of harmful algal blooms as health threats to marine wildlife. In: Aguirre, A.A., Ostfeld, R., Daszak, P. (Eds.), New Directions in Conservation Medicine: Applied Cases of Ecological Health. Oxford University Press, New York, pp. 374-389.

Fire, S.E., Wang, Z.H., Berman, M., Langlois, G.W., Morton, S.L., Sekula-Wood, E. Benitez-Nelson, C.R., 2010. Trophic transfer of the harmful algal toxin domoic acid as a cause of death in a minke whale (Balaenoptera acutorostrata) stranding in southern California. Aquat. Mammals 36, 342-350.

Fraga, S., Álvarez, M.J., Míguez, A., Fernández, M.L., Costas, E., López-Rodas, V., 1998. Pseudo-nitzschia species isolated from Galician waters: toxicity, DNA content and lectin binding assay. In: Reguera, B., Blanco, J., Fernández, M.L., Wyatt, T. (Eds.), Harmful Microalgae. Xunta de Galicia \& UNESCO, Paris, pp. 270-273.

Fritz, L., Quilliam, M.A., Wright, J.L.C., Beale, A.M., Work, T.M., 1992. An outbreak of domoic acid poisoning attributed to the pennate diatom Pseudo-nitzschia australis. J. Phycol. 28, 439-442.

Garrison, D.L., Conrad, S.M., Eilers, P.P., Waldron, E.M., 1992. Confirmation of domoic acid production by Pseudo-nitzschia australis (Bacillariophyceae) in culture. J. Phycol. 28, 604-607.

Guannel, M.L., Horner-Devine, M.C., Rocap, G., 2011. Bacterial community composition differs with species and toxigenicity of the diatom Pseudonitzschia. Aquat. Microb. Ecol. 64, 117-133.

Guannel, M.L., Haring, D., Twiner, M.J., Wang, Z., Noble, A.E., Lee, P.A., Saito, M.A., Rocap, G., 2015. Toxigenicity and biogeography of the diatom Pseudo-nitzschia across distinct environmental regimes in the South Atlantic Ocean. Mar. Ecol. Prog. Ser. 526, 67-87.

HarĐardóttir, S., Pančić, M., Tammilehto, A., Krock, B., Møller, E.F., Nielsen, T.G., Lundholm, N., 2015. Dangerous relations in the Arctic marine food web: interactions between toxin producing Pseudo-nitzschia diatoms and Calanus copepodites. Mar. Drugs 13, 3809-3835.

Kapetzki, J.M., Aguilar-Manjarrez, J., Jenness, J., 2013. A global assessment of offshore mariculture potential from a spatial perspective. Food and Agriculture Organization of the United Nations Paper No. 549, Rome.

Kotaki, Y., Lundholm, N., Onodera, H., Kobayashi, K., Bajarias, F.F.A., Furio, E.F., Iwataki, M., Fukuyo, Y., Kodama, M., 2004. Wide distribution of Nitzschia navisvaringica, a new domoic acid-producing benthic diatom found in Vietnam. Fish. Sci. 70, 28-32.

Krock, B., Tillmann, U., John, U., Cembella, A.D., 2008. LC-MS/MS on board ship tandem mass spectrometry in the search for phycotoxins and novel toxigenic plankton from the North Sea. Anal. Bioanal. Chem. 392, 797-803.

Krock, B., Borel, C.M., Barrera, F., Tillmann, U., Fabro, E., Almandoz, G.O., Ferrario, M. E., Garzón Cardona, J.E., Koch, B.P., Alonso, C., Lara, R., 2015. Analysis of the hydrographic conditions and cyst beds in the San Jorge Gulf, Argentina, that favor dinoflagellate population development including toxigenic species and their toxins. J. Mar. Syst. 148, 86-100.

Lelong, A., Hégaret, H., Soudant, P., Bates, S.S., 2012. Pseudo-nitzschia (Bacillariophyceae) species, domoic acid and amnesic shellfish poisoning: revisiting previous paradigms. Phycologia 51, 168-216.

Li, Y., Ma, Y.Y., Lu, S.H., 2010. Morphological characteristics of Pseudo-nitzschia americana complex in Daya Bay, China. Acta Hydrobiol. Sin. 34, 851-855.

Lim, H.C., Leaw, C.P., Su, S.N.P., Teng, S.T., Usup, G., Mohammad-Noor, N., Lundholm, N., Kotaki, Y., Lim, P.T., 2012a. Morphology and molecular characterization of Pseudo-nitzschia (Bacillariophyceae) from Malaysian Borneo, including the new species Pseudo-nitzschia circumpora sp. nov. J. Phycol. 48, 1232-1247.
Lim, H.C., Lim, P.T., Su, S.N.P., Teng, S.T., Leaw, C.P., 2012b. Genetic diversity of Pseudonitzschia brasiliana (Bacillariophyceae) from Malaysia. J. Appl. Phycol. 24, 14651475.

Lim, H.C., Teng, S.T., Leaw, C.P., Lim, P.T., 2013. Three novel species in the Pseudonitzschia pseudodelicatissima complex $P$. batesiana sp. nov., P. lundholmiae $\mathrm{sp}$. nov., and P. fukuyoi sp. nov. (Bacillariophyceae) from the Strait of Malacca, Malaysia. J. Phycol. 49, 902-916.

Lundholm, N., Moestrup, Ø., 2000. Morphology of the marine diatom Nitzschia navis-varingica sp. nov. (Bacillariophyceae), another producer of the neurotoxin domoic acid. J. Phycol. 36, 1162-1174.

Lundholm, N., Hasle, G.R., Fryxell, G.A., Hargraves, P.E., 2002. Morphology, phylogeny and taxonomy of species within the Pseudo-nitzschia americana complex (Bacillariophyceae) with descriptions of two new species, Pseudonitzschia brasiliana and Pseudo-nitzschia linea. Phycologia 41, 480-497.

Lundholm, N., Moestrup, Ø., Hasle, G.R., Hoef-Emden, K., 2003. A study of the Pseudo-nitzschia pseudodelicatissima/cuspidata complex (Bacillariophyceae): what is P. pseudodelicatissima? J. Phycol. 39, 797-813.

Lundholm, N., Moestrup, Ø., Kotaki, Y., Hoef-Emden, K., Scholin, C., Miller, P., 2006. Inter- and intraspecific variation of the Pseudo-nitzschia delicatissima complex (Bacillariophyceae) illustrated by rRNA probes, morphological data and phylogenetic analyses. J. Phycol. 42, 464-481.

Míguez, A., Fernández, M.L., Fraga, S., 1996. First detection of domoic acid in Galicia (NW of Spain). In: Yasumoto, T., Oshima, Y., Fukuyo, Y. (Eds.), Harmful and Toxic Algal Blooms. IOC UNESCO, Paris, pp. 143-145.

Maneiro, I., Iglesias, P., Guisande, C., Riveiro, I., Barreiro, A., Zervoudaki, S., Graneli, E. 2005. Fate of domoic acid ingested by the copepod Acartia clausi. Mar. Biol. 148 123-130.

Marchetti, A., Trainer, V.L., Harrison, P.J., 2004. Environmental conditions and phytoplankton dynamics associated with Pseudo-nitzschia abundance and domoic acid in the Juan de Fuca eddy. Mar. Ecol. Prog. Ser. 281, 1-12.

Marchetti, A., Lundholm, N., Kotaki, Y., Hubbard, K., Harrison, P.J., Armbrust, V.E. 2008. Identification and assessment of domoic acid production in oceanic Pseudo-nitzschia (Bacillariophyceae) from iron-limited waters in the northeast subarctic Pacific. J. Phycol. 44, 650-661.

McCabe, R.M., Hickey, B.M., Kudela, R.M., Lefebvre, K.A., Adams, N.G., Bill, B.D. Gulland, F.M.D., Thomson, R.E., Cochlan, W.P., Trainer, V.L., 2016. An unprecedented coastwide toxic algal bloom linked to anomalous ocean conditions. Geophys. Res. Lett. 43 doi:http://dx.doi.org/10.1002/2016gl070023.

Montoya, N.G., Negri, R.M., Carignan, M.O., Carreto, J.I., 2008. Algunas características bioquímicas de la diatomea tóxica Pseudo-nitzschia multiseries aislada en el Mar Argentino. Anales del XI Congreso Brasilero de Ficología y Simposio Latinoamericano sobre algas nocivas. Museo Nacional. Serie Livros 30, 259-266.

Negri, R.M., Inza, D., 1998. Some potentially toxic species of Pseudo-nitzschia in the Argentine Sea $\left(35^{\circ}-39^{\circ}\right.$ S). In: Reguera, B., Blanco, J., Fernández, M.L., Wyatt, T. (Eds.), Proceedings of the VIII International Conference on Harmful Algae. Xunta de Galicia and IOC of UNESCO Publishers, Vigo, pp. 84-85.

Negri, R.M., Montoya, N.G., Carreto, J.I., Akselman, R., Inza, D., 2004. Pseudo-nitzschid australis, Mytilus edulis, Engraulis anchoita, and domoic acid in the Argentine Sea. In: Steidinguer, K.A., Landsberg, J.H., Tomas, C.R., Vargo, G.A. (Eds.), Harmful Algae 2002. Florida Fish and Wildlife Conservation Commission, Florida Institute of Oceanography, and Intergovernmental Oceanographic Commission of UNESCO, St. Petersburg, Florida, USA, pp. 139-141.

Orive, E., Pérez-Aicua, L., David, H., García-Etxebarria, K., Laza-Martínez, A., Seoane, S., Miguel, I., 2013. The genus Pseudo-nitzschia (Bacillariophyceae) in a temperate estuary with description of two new species: Pseudo-nitzschia plurisecta sp. nov. and Pseudo-nitzschia abrensis sp. nov. J. Phycol. 49, 1192-1206.

Percopo, I., Ruggiero, M.V., Balzano, S., Gourvil, P., Lundholm, N., Siano, R., Tammilehto, A., Vaulot, D., Sarno, D., 2016. Pseudo-nitzschia arctica sp. nov.: a new cold-water cryptic Pseudo-nitzschia species within the P. pseudodelicatissima complex. J. Phycol. 52, 184-199.

Prygiel, J., Coste, M., 2000. Guide Méthodologique pour la mise en ouvre de l'Indice Biologique Diatomées. Agence de l'Eau. Ministiére de l'Ammagement du Territoire et de l'Environment, Direction de l'Eau \& CEMAGREF, France.

Quijano-Scheggia, S., Garcés, E., Van Lenning, K., Sampedro, N., Camp, J., 2005. First detection of diatom Pseudo-nitzschia brasiliana (non toxic) and its relative $P$. multistriata (presumably toxic) in the NW Mediterranean Sea. Harmful Algae News 29, 5.

Quijano-Scheggia, S., Garcés, E., Andree, K.B., De la Iglesia, P., Diogène, J., Fortuño, J. M., Camp, J., 2010. Pseudo-nitzschia species on the Catalan coast: characterization and contribution to the current knowledge of the distribution of this genus in the Mediterranean Sea. Sci. Mar. 74, 395-410.

RMCP, 2013. Relevamiento de la actividad de maricultura en la patagonia Argentina. Red de fortalecimiento para la maricultura costera patagónica. Documento técnico \# 1/2013, Puerto Madryn, Argentina.

Rhodes, L., White, D., Syhre, M., Atkinson, M., 1996. Pseudo-nitzschia species isolated from New Zealand coastal waters: domoic acid production in vitro and links with shellfish toxicity. In: Yasumoto, T., Oshima, Y., Fukuyo, Y. (Eds.), Harmful and Toxic Algal Blooms. IOC of UNESCO, Paris, pp. 155-158.

Rhodes, L., Scholin, C., Garthwaite, I., Haywood, A., Thomas, A., 1998a. Domoic acid producing Pseudo-nitzschia species educed by whole cell DNA probe-based and immunochemical assays. In: Reguera, B., Blanco, I., Fernández, M.L., Wyatt, T. (Eds.), Harmful Algae. Xunta de Galicia and the Intergovernmental Oceanographic Commission of UNESCO, Paris, pp. 274-277.

Rhodes, L.L., Scholin, C., Garthwaite, I., 1998b. Pseudo-nitzschia in New Zealand and the role of DNA probes and immunoassays in refining marine biotoxin monitoring programmes. Nat. Toxins 6, 105-111. 
Romero, M.L.J., Kotaki, Y., Lundholm, N., Thoha, H., Ogawa, H., Relox, J.R., Terada, R., Takeda, S., Takata, Y., Haraguchi, K., Endo, T., Lim, P.T., Kodama, M., Fukuyo, Y., 2011. Unique amnesic shellfish toxin composition found in the Southeast Asian diatom Nitzschia navis-varingica. Harmful Algae 10, 456-462.

Sahraoui, I., Bates, S.S., Bouchouicha, D., Mabrouk, H.H., Hlaili, A.S., 2011. Toxicity of Pseudo-nitzschia populations from Bizerte Lagoon Tunisia, southwest Mediterranean, and first report of domoic acid production by P. brasiliana. Diatom Res. 26, 293-303.

Sahraoui, I., Grami, B., Bates, S.S., Bouchouicha, D., Chikhaoui, M.A., Mabrouk, H.H., Hlaili, A.S., 2012. Response of potentially toxic Pseudo-nitzschia (Bacillariophyceae) populations and domoic acid to environmental conditions in eutrophied, SW Mediterranean coastal lagoon (Tunisia). Estuar. Coast. Shelf Sci. 102, 95-104.

Sar, E.A., Andrinolo, D., Sunesen, I., 2006. Análisis morfológico y toxicológico de cultivos de Pseudo-nitzschia pungens var. pungens (Bacillariophyceae). Bol. Soc. Argent. Bot. 41, 193-201.

Sastre, A., Santinelli, N., Esteves, J., Ferrario, M., 2001. Aspectos ecológicos de especies de Pseudo-nitzschia en aguas costeras patagónicas (Argentina). In: Alveal, K., Antezana, T. (Eds.), Sustentabilidad de la biodiversidad. Universidad de Concepción, Concepción, pp. 217-235.

Sastre, A., Santinelli, N., Marino, G., Solís, M., Pujato, L., Ferrario, M., 2007. First detection of domoic acid produced by Pseudo-nitzschia species Chubut coastal waters, Patagonia, Argentina. Harmful Algae News 34, 12-14.

Schnetzer, A., Miller, P.E., Schaffner, R.A., Stauffer, B.A., Jones, B.H., Weisberg, S.B., DiGiacomo, P.M., Berelson, W.M., Caron, D.A., 2007. Blooms of Pseudo-nitzschia and domoic acid in the San Pedro Channel and Los Angeles harbor areas of the Southern California Bight, 2003-2004. Harmful Algae 6, 372-387.

Scholin, C.A., Gulland, F., Doucette, G.J., Benson, S., Busman, M., Chavez, F.P., Cordaro, J., DeLong, R., De Vogelaere, A., Harvey, J., Haulena, M., Lefebvre, K., Lipscomb, T., Loscutoff, S., Lowenstine, L.J., Marin, R., Miller, P.E., McLellan, W.A., Moeller, P.D R., Powell, C.L., Rowles, T., Silvagni, P., Silver, M., Spraker, T., Trainer, V., Van Dolah, F.M. 2000. Mortality of sea lions along the central California coast linked to a toxic diatom bloom. Nature 403, 80-83.

Sierra-Beltrán, A., Palafox-Uribe, M., Grajales-Montiel, J., Cruz-Villacorta, A., Ochoa, J.L., 1997. Sea bird mortality at Cairo San Lucas, Mexico: evidence that toxic diatom blooms are spreading. Toxicon 35, 447-453.

Smida, D.B., Lundholm, N., Kooistra, W.H., Sahraoui, I., Ruggiero, M.V., Kotaki, Y., Ellegaard, M., Lambert, C., Mabrouk, H.H., Hlaili, A.S., 2014. Morphology and molecular phylogeny of Nitzschia bizertensis sp. nov. - A new domoic acidproducer. Harmful Algae 32, 49-63.

Sunesen, I., Bárcena, A., Sar, E.A., 2009. Diatomeas potencialmente nocivas del Golfo San Matías (Argentina). Rev. Biol. Mar. Oceanogr. 44, 67-88.

Tammilehto, A., Nielsen, T.G., Krock, B., Møller, E.F., Lundholm, N., 2015. Induction of domoic acid production in the toxic diatom Pseudo-nitzschia seriata by calanoid copepods. Aquat. Toxicol. 159, 52-61.
Tan, S.N., Teng, S.T. Lim, H.C., Kotaki, Y., Bates, S.S., Leaw, C.P., Lim, P.T., 2016. Diatom Nitzschia navis-varingica (Bacillariophyceae) and its domoic acid production from the mangrove environments of Malaysia. Harmful Algae 60, 139-149.

Tatters, A.O.,Fu,F.X.,Hutchins, D.A.,2012.High $\mathrm{CO}_{2}$ and silicatelimitationsynergistically increase the toxicity of Pseudo-nitzschia fraudulenta. PLoS One 7, e32116.

Teng, S.T., Lim, H.C., Lim, P.T., Dao, V.H., Bates, S.S., Leaw, C.P., 2014. Pseudo-nitzschia kodamae sp. nov. (Bacillariophyceae) a toxigenic species from the Strait of Malacca, Malaysia. Harmful Algae 34, 17-28.

Teng, S.T., Lim, P.T., Lim, H.C., Rivera-Vilarelle, M., Quijano-Scheggia, S., Takata, Y., Quilliam, M.A., Wolf, M., Bates, S.S., Leaw, C.P., 2015. A non-toxigenic but morphologically and phylogenetically distinct new species of Pseudo-nitzschia, P. sabit sp. nov. (Bacillariophyceae). J. Phycol. 51, 706-725.

Teng, S.T., Tan, S.N., Lim, H.C., Dao, V.H., Bates, S.S., Leaw, C.P., 2016. High diversity of Pseudo-nitzschia along the northern coast of Sarawak (Malaysian Borneo), with descriptions of $P$. bipertita sp. nov. and P. limii sp. nov. (Bacillariophyceae). J. Phycol. doi:http://dx.doi.org/10.1111/jpy.12448.

Tester, P.A., Pan, Y., Doucette, G.J., Scholin, C.A., 2001. Accumulation of domoic acid activity in copepods. In: Hallegraeff, G.M., Blackbum, S.I., Bolch, C.J., Lewis, R.J. (Eds.), Harmful Algal Blooms 2000. Intergovernmental Oceanographic Commission of UNESCO, pp. 418-421.

Thessen, A.E., Stoecker, D.K., 2008. Distribution, abundance and domoic acid analysis of the toxic diatom genus Pseudo-nitzschia from the Chesapeake Bay. Estuar. Coast. 31, 664-672.

Thessen, A.E., Bowers, H.A., Stoecker, D.K., 2009. Intra-and interspecies differences in growth and toxicity of Pseudo-nitzschia while using different nitrogen sources. Harmful Algae 8, 792-810.

Trainer, V.L., Bates, S.S., Lundholm, N., Thessen, A.E., Cochlan, W.P., Adams, N.G., Trick, C.G., 2012. Pseudo-nitzschia physiological ecology, phylogeny, toxicity, monitoring and impacts on ecosystem health. Harmful Algae 14, 271-300.

Trick, C.G., Bill, B.D., Cochlan, W.P., Wells, M.L., Trainer, V.L., Pickell, L.D., 2010. Iron enrichment stimulates toxic diatom production in high-nitrate, low-chlorophyll areas. Proc. Natl. Acad. Sci. 107, 5887-5892.

Utermöhl, H., 1958. Zur vervollkommnung der quantitativen phytoplanktonmethodik. Mitt. Int. Ver. Theor. Angew. Limnol. 9, 1-38.

Villac, M.C., Roelke, D.L., Chávez, F.P., Cifuentes, L.A., Fryxell, G.A., 1993. Pseudonitzschia australis Frenguelli and related species from the west coast of the U.S. A.: Occurrence and domoic acid production. J. Shellfish Res. 12, 457-465.

Wang, P., Liang, J., Lin, X., Chen, C., Huang, Y., Gao, Y., Gao, Y., 2012. Morphology, phylogeny and ITS-2 secondary structure of Pseudo-nitzschia brasiliana (Bacillariophyceae), including Chinese strains. Phycologia 51,1-10.

Wilson, C., Sastre, A.V., Hoffmeyer, M., Rowntree, V.J., Fire, S.E., Santinelli, N.H., Diaz Ovejero, S., D'Agostino, V., Maron, C.F., Doucette, G.J., Broadwater, M.H., Wang, Z., Montoya, N., Seger, J., Alder, F.R., Sironi, M., Uhart, M.M., 2015. Southern right whale (Eubalaena australis) calf mortality at Península Valdes, Argentina: are harmful algal blooms to blame? Mar. Mam. Sci. doi:http://dx.doi.org/10.1111/ mms.12263. 